\title{
THE TREATMENT OF KALA AZAR IN CHILDREN
}

\author{
BY \\ ANNIE V. SCOTT, M.D., and P. K. LI, M.B. \\ (From the Children's Medical Service, Cheeloo Hospital, Tsinan, Shantung, \\ China.)
}

In an earlier number of the Archives ${ }^{1}$ the writers gave an account of the clinical symptoms and laboratory findings in cases of kala azar as they had seen it in the children of North China. The following paper is a continuation of the subject, reporting the results, so far as they were ascertainable, of treatment in the same districts.

The efficacy of antimony in the treatment of kala azar was established before the period covered by these observations. China gave antimony to the world ${ }^{2}$, but the honour of its successful introduction and application in the treatment of kala azar belongs chiefly to Napier and to Brahmachari of India. The compounds of antimony now in use for the treatment of kala azar are direct results of the careful clinical observations made by these two workers. It is indeed an inspiring story to follow the clinicians and chemists co-operating to eliminate one difficulty after another; until in $1928 \mathrm{Napier}^{3}$ could say: 'Thirteen years ago the death rate in kala azar was said to be 95 per cent., whereas now, at whatever stage of the disease the patients first come under treatment, the recovery rate should be at least 95 per cent.' Our own small series of cases illustrates well the strides which have been made since the introduction of tartar emetic for the treatment of kala azar.

The present study is an attempt to collect data, from hospital records and from patients, which may be of use in estimating the value of various antimony preparations in the treatment of kala azar in children. All cases reported in this study showed the presence of Leishmania donovani bodies in films made from puncture of the spleen or liver, or both.

Antimony preparations.-The antimony preparations used for the treatment of the cases reported were:-

Tartar emetic. Potassium antimony tartrate, sodium antimony tartrate and the Burroughs Wellcome preparation of antimony and sodium tartrate, 2 parts, to sodium chloride, 1 part, are included in this group. The 
solution, either 1 or 2 per cent., was made in freshly distilled sterile water or sterile saline. A freshly prepared solution was used. Injections were given intravenously every third day, unless there was indication that a longer interval between doses was advisable. In most cases, the initial dose was $\frac{1}{2}$ c.cm., which was very gradually increased. More than $4 \mathrm{c.cm}$. of a 1 per cent. solution was rarely given. Reactions were not unusual following the use of this drug. The most frequent reaction observed was severe coughing, with expectoration of blood-stained sputum, accompanied by cyanosis, dyspnœa and fever. Such a reaction followed immediately upon the intravenous injection of the drug and all the symptoms except fever passed off within a very short time. Nausea and vomiting were not unusual, either accompanying such attacks as are described above, or alone. If any of the solution escaped into the surrounding tissues during administration, there was immediate acute pain, soon followed by redness and swelling of the area infiltrated, and often resulting in necrosis of the involved tissues.

Antimosan (Heyden 661). This is a complex salt of antimony oxide and a non-toxic derivative of pyrocatechin. It contains trivalent antimony, about 12.5 per cent. ${ }^{4}$ This drug was prepared in sterile distilled water, 5 per cent. solution, and given intravenously, beginning with 1 and gradually increasing to $2 \mathrm{c.cm}$. It was possible to give the drug on successive days, but in most cases it was given on alternate days.

Stibamine glucoside. This is an aromatic compound allied to sodium para-amino-phenyl-stibiate, with an antimony content of about 30 per cent. This drug was dissolved in sterile distilled water. In most of the cases, a 2 per cent. solution was used. The injections were given intravenously, beginning with $0.03 \mathrm{grm}$. of the drug every third day, and gradually increasing to $0.1 \mathrm{grm}$. in about two weeks. This dose was continued, if no unfavourable syrnptoms developed, until the total quantity was administered.

Stibosan (Heyden 471). This name is given to meta-chlor-para-acetylamino-phenyl stibiate of sodium, an organic preparation containing 31 per cent. of antimony ${ }^{4}$. The drug was prepared as a 2 per cent. solution in sterile distilled water, and given intravenously, on alternate days, in doses beginning at $\cdot 03 \mathrm{grm}$. and increasing $\cdot 01$. for each injection until $0 \cdot 1 \mathrm{grm}$. was reached. This quantity was continued, if no unfavourable symptoms developed, until the full amcunt of the drug had been given.

Neostibosan (693). This is an amine salt of para-amino-phenylstibinic acid, containing approximately 42 per cent. of pentavalent antimony firmly attached to carbon. After being used for three years, the preparation was so modified in 1927 that it is said to be no longer emetic when administered in large doses. This drug has been used by us in 5 per cent. solution, made up in sterile distilled water. The drug may be given intravenously or intramuscularly. We have given full treatments intramuscularly and have observed no pain or local reaction following the 
injections. In a few of our cases there has been nausea immediately following intravenous administration of the drug. The initial dose of drug given is $0.05 \mathrm{grm}$. which is usually increased to $0.1 \mathrm{grm}$. at the second injection. This dosage is used for two or three injections, when it is increased to $0.2 \mathrm{grm}$. for the remainder of the treatment. If the child is in fairly good condition, or if he has noma, the injections are given daily. We have found that children who have diarrhœa or dysentery do not do well with daily injections.

Except in the case of the first-named preparation, a reaction following injection was rare. If it occurred, it consisted in nausea developing soon after intravenous injection of the drug and soon disappearing. A few such reactions have been observed with neostibosan, even during the early course of injections.

We have observed that the few cases treated in our clinic and not admitted to hospital, usually ran a fever to the end of the treatment and did not show as marked early blood repair as patients who enter hospital and remain in bed during the greater part of the time they are receiving the injections.

Diet.-The diet is such an important part of the treatment of kala azar in a child that we feel warranted in outlining the routine diet ordered. The appetite is usually good and, even in the cases where the fever is high, we find that the patients do well on the following diet:-

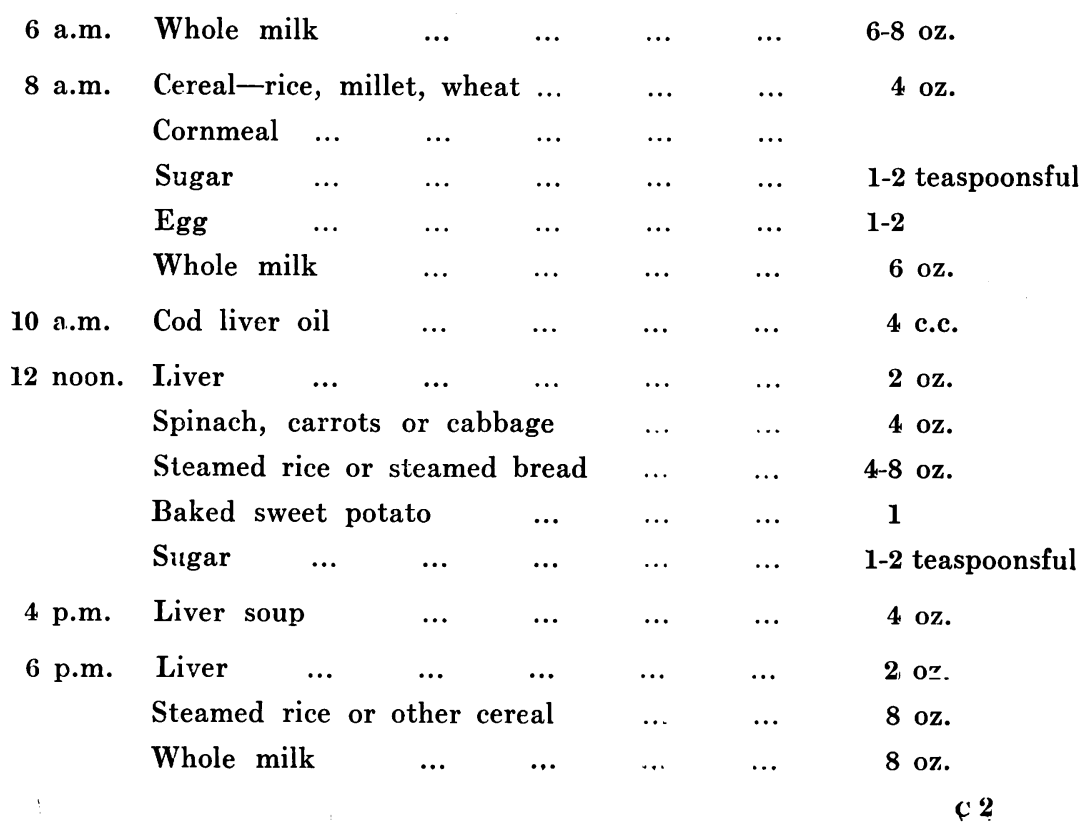


For the sake of convenience, the antimony preparations used are designated by letters, as indicated in Table 1. Facts concerning the patients treated by these antimony preparations are arranged in corresponding groups designated A, B, C, D, E, F respectively. Owing to the small number of cases in groups $\mathbf{B}$ and $\mathbf{F}$, these groups are not included in the detailed study of the cases. Of the 134 patients in Table 1, 3 were discharged against advice before treatment was finished, and 22 died during the course of treatment.

TABLE 1.

SyNOPSIS OF TREATMENT IN 134 CASES.

\begin{tabular}{|c|c|c|c|c|c|}
\hline \multicolumn{2}{|c|}{ Reference letter. } & \multicolumn{2}{|c|}{ Antimony preparation. } & No. of cases. & Date of treatment. \\
\hline (a) & $\ldots$ & Sodium antimony ta & ate & 73 & July 4, 1921-May 10,1925 \\
\hline (b) & $\cdots$ & Antimosan, 661 & $\ldots$ & 3 & Nov., $1924-F e b ., 1925$ \\
\hline (c) & $\cdots$ & Stibamine glucoside & $\cdots$ & 8 & Feb., 1926-Nov., 1927 \\
\hline$(\mathrm{d})$ & $\cdots$ & Stibosan, $471 \quad \ldots$ & $\therefore$ & 13 & Aug., 1924--Dec., 1928 \\
\hline (e) & $\cdots$ & Neostibosan $\quad \ldots$ & $\cdots$ & $3 t$ & July, 1928-Mar., 1931 \\
\hline (f) & $\cdots$ & $(b)+(d)+(c)$ & $\cdots$ & 1 & April, 1926 \\
\hline , , & $\cdots$ & $(c)+(e)$ & $\ldots$ & 1 & Sept., 1926 \\
\hline , & $\ldots$ & $(\mathrm{d})+(\mathrm{e})$ & $\cdots$ & 1 & Aug., 1924 \\
\hline
\end{tabular}

TABLE 2.

Fatal Cases in aUthors' SERIEs.

\begin{tabular}{|c|c|c|c|c|c|c|c|}
\hline \multirow{2}{*}{\multicolumn{5}{|c|}{ Primary diagnosis. }} & \multicolumn{3}{|c|}{ Antimony preparation. } \\
\hline & & & & & \multirow{2}{*}{ (a) } & \multirow{2}{*}{ (f) } & \multirow{2}{*}{ (e) } \\
\hline Bronchopueumonia & $\cdots$ & $\cdots$ & $\cdots$ & $\cdots$ & & & \\
\hline Dysentery $\ldots$ & $\ldots$ & $\cdots$ & $\cdots$ & $\cdots$ & 1 & - & 一 \\
\hline Bronchitis $\ldots$ & $\cdots$ & $\cdots$ & $\cdots$ & $\cdots$ & 1 & - & 一 \\
\hline Necrosis around inje & ction & $\cdots$ & $\cdots$ & $\cdots$ & 1 & 1 & $-\cdots$ \\
\hline Cancrum oris & $\cdots$ & $\cdots$ & $\cdots$ & $\cdots$ & 2 & -- & - \\
\hline Lobar f neumonia & $\cdots$ & $\cdots$ & $\cdots$ & $\ldots$ & 3 & 1 & - \\
\hline Acute odema of lun & & $\cdots$ & $\cdots$ & $\cdots$ & - & 1 & 一 \\
\hline Maliutrition & $\cdots$ & $\cdots$ & $\cdots$ & $\cdots$ & - & 1 & $\cdots$ \\
\hline Hookworm disease & $\ldots$ & $\cdots$ & $\cdots$ & $\cdots$ & - & 1 & 一 \\
\hline Cause not establishe & & ... & $\ldots$ & $\ldots$ & 1 & - & - \\
\hline
\end{tabular}

Table 2 shows the cause of death in the patients who died during treatment and the antimony preparation used in treating the kala azar, 
Table 3 shows the list of diseases complicating kala azar in our series of children. The period during treatment is practically covered by the services of two physicians. The change of physicians was made in 1924. We feel, from our more recent investigations, that the incidence of spirochætal

TABLE 3.

COMPlications of Kala AZAR IN AUthors' SERIES.

\begin{tabular}{|c|c|c|c|c|c|c|c|c|c|c|}
\hline \multirow{2}{*}{\multicolumn{2}{|c|}{ Disease. }} & \multicolumn{3}{|c|}{ Treatment (a) } & \multicolumn{3}{|c|}{$\begin{array}{l}\text { Treatment } \\
\text { (b), (c), (d) \& (f) }\end{array}$} & \multicolumn{3}{|c|}{ Treatment (e) } \\
\hline & & before & during & after & before & during & after & before & during & after \\
\hline Ascariasis & $\ldots$ & 34 & - & - & 16 & - & - & 20 & - & - \\
\hline Bronchitis & $\ldots$ & 9 & 13 & 4 & 4 & 5 & - & 4 & 2 & - \\
\hline Bronchopneumonia & $\ldots$ & 13 & 15 & 13 & 5 & 5 & 5 & 2 & 3 & -- \\
\hline Cancrum oris $\quad \ldots$ & $\ldots$ & 4 & 5 & 3 & 4 & 3 & - & 5 & 4 & 2 \\
\hline Diarrhœa & $\cdots$ & 4 & 2 & 1 & - & 1 & -- & 1 & 2 & - \\
\hline Dysentery, amœbic & $\ldots$ & - & - & - & 1 & - & - & - & - & - \\
\hline,$\quad$ bacillary & $\ldots$ & - & - & - & - & - & - & 1 & 1 & - \\
\hline Edema of lungs, acute & $\ldots$ & -- & - & - & - & 1 & - & - & - & - \\
\hline Otitis media, acute & $\ldots$ & - & 2 & 1 & - & - & - & 5 & 5 & 2 \\
\hline$" \quad, \quad$ chronic & $\ldots$ & 3 & 3 & 1 & 3 & 3 & 1 & - & - & - \\
\hline Mastoiditis $\quad \ldots$ & $\cdots$ & - & 1 & 1 & - & - & - & - & - & - \\
\hline Nephritis & $\cdots$ & 2 & 2 & 2 & 1 & 1 & - & - & - & - \\
\hline Hookworm disease & $\ldots$ & 4 & 2 & - & 4 & 4 & - & 1 & 1 & - \\
\hline Heart disease, mitral & $\cdots$ & - & - & - & 1 & 1 & 1 & - & - & 一 \\
\hline Tuberculosis, hilum & $\cdots$ & - & - & - & 1 & 1 & 1 & - & - & - \\
\hline peritoneal & & - & - & - & 1 & 1 & $\mathbf{i}$ & - & - & - \\
\hline pulmonary & & 1 & 1 & 1 & - & - & - & - & -- & - \\
\hline Inflammation around injec & ction & - & 1 & - & - & - & - & - & - & - \\
\hline Spirochætal infection gun & & 1 & 1 & 1 & 3 & 2 & 1 & 1!) & 19 & 19 \\
\hline Syphilis, congenital & $\ldots$ & 2 & 2 & 2 & - & - & - & - & - & - \\
\hline Lobar pneumonia & $\cdots$ & 2 & 4 & - & - & 1 & - & - & - & - \\
\hline Cervical adenitis, acute & $\ldots$ & 7 & 8 & 5 & - & - & - & 1 & 1 & - \\
\hline Pyorrhœa alveolaris &.. & 22 & $2 !$ & 15 & 2 & 2 & 2 & 7 & 7 & 3 \\
\hline Caries of teeth $\ldots$ & $\ldots$ & 9 & 9 & 9 & 1 & 1 & 1 & 2 & 1 & 1 \\
\hline
\end{tabular}


infection of gums and intestinal infection with dysentery bacilli is low in the early histories because, at that time, laboratory routine did not include examination for these two infections.

Results of Treatment.-Observations made on the patients subdivided into various groups according to the preparation of antimony used will now be given. Some illustrative case histories are added.

Group A. Taking first the group of cases treated with sodium antimony tartrate the results are shown in the following list and Table 4.

Number of cases treated, 67.

Average age, $8 \frac{1}{2}$ years.

Average duration kala azar before admission, $10 \frac{1}{2}$ months.

Liver puncture positive $L$. donovani, 65, 6 not done.

Spleen puncture positive L. donovani, 7, 60 not done.

Average days in hospital, 104.

Total average dose of drug, $0.87 \mathrm{grm}$.

Average number of injections, 37.

Average number of injections to fall of temperature, 26.

Average amount of drug to fall of temperature, $0.81 \mathrm{grm}$.

TABLE 4.

RESULTS OF TREATMENT BY SODIUM ANTIMONy TARTRATE.

\begin{tabular}{|c|c|c|c|c|c|c|c|}
\hline & & \multicolumn{2}{|c|}{ Before treatment. } & \multicolumn{2}{|c|}{ After treatment. } & \multirow{2}{*}{$\begin{array}{c}\text { Before: } \\
\text { Average. }\end{array}$} & \multirow{2}{*}{$\begin{array}{c}\text { After : } \\
\text { Average }\end{array}$} \\
\hline & & Max. & Min. & Max. & Min. & & \\
\hline Body wt., kgrm. & $\ldots$ & - & - & - & - & $19 \cdot 852$ & $29 \cdot 503$ \\
\hline Size liver, cm. & $\ldots$ & 10 & 0.3 & 10 & 0.5 & $4 \cdot 5$ & 4 \\
\hline Size spleen, cm. & $\ldots$ & 25 & $1 \cdot 5$ & 25 & 0.5 & $13 \cdot 5$ & $7 \cdot 8$ \\
\hline Hæmoglobin, per cen & & 80 & 30 & 90 & 35 & $5 t \cdot 1$ & $67 \cdot 3$ \\
\hline Red blood cells & $\ldots$ & $4,984,000$ & $1,020,000$ & $5,430,000$ & 940,000 & $3,965,547$ & $4,234,000$ \\
\hline White blood cells & $\ldots$ & 12,000 & 1,100 & 12,300 & 600 & 4,224 & $6,626,000$ \\
\hline
\end{tabular}

Illustrative Case (Group A).-Male, about 5 years of age, ill with kala azar 24 months, spleen enlarged 18 months. The child was treated with one per cent. solution of sodium antimony tartrate intravenously. The initial dose was $0.5 \mathrm{c.cm}$. The dose was gradually increased to $3 \mathrm{c.cm}$. near the end of the treatment. Three injections were given each week, excepting the fifth and sixth weeks, when the drug was withheld because of enlarged tender cervical glands. At the end of five months, the patient had received $76 \mathrm{c.cm}$. of the drug. Reactions following injections were, enlarged tender cervical glands noted above, and an attack of coughing following an injection, when the total amount of $27.5 \mathrm{c.cm}$. had been given. By the end of the course of treatment the enlargement of the spleen had diminished from $17 \mathrm{~cm}$. to $9.5 \mathrm{~cm}$., the hæmoglobin had increased from 50 to 90 per cent., and the red blood cells from $2,895,000$ to $5,760,000$. There was a gain in weight of $2.5 \mathrm{kgrm}$. A letter 
and a detailed report written six years after the course of treatment indicated that this treatment had cured the kala azar.

Groups C and D. These groups consist of the cases treated with stibamine glucoside and stibosan 471. The results obtained in these groups are given in the following list and Tables 5 and 6 ; and an illustrative case from each group is briefly recounted.

$\begin{array}{llllcc}\text { Number of cases treated } & & & \text { Group C. } & \text { Group } 1 \text {. } \\ \text { Average age } \ldots & \ldots & \ldots & 8 & 12 \\ \text { Average duration kala azar before admission } & \ldots & \mathbf{8} \text { years } & 8 \text { years } \\ \text { Liver puncture positive for L. donovani } & \ldots & 8 & 23 \text { mos. } \\ \text { Total average days in hospital } & \ldots & \ldots & 78 & 12 \\ \text { Total average dose of drug grams } & \ldots & \ldots & 1 \cdot 54 & 1 \cdot 87 \\ \text { Average number injections } \ldots & \ldots & \ldots & 18 & 22 \\ \text { Average quantity of drug to fall of temperature } & 0 \cdot 9 & 1 \cdot 2\end{array}$

TABLE 5 .

Group C: Results of treatment by Stibamine GluCoside.

\begin{tabular}{|c|c|c|c|c|c|c|}
\hline & \multicolumn{2}{|c|}{ Before treatment, } & \multicolumn{2}{|c|}{ After treatment. } & \multirow{2}{*}{ Before: } & \multirow{2}{*}{$\begin{array}{c}\text { After : } \\
\text { Average. }\end{array}$} \\
\hline & Max. & Min. & Max. & Min. & & \\
\hline Body wt., kgrm. & - & - & - & - & $18 \cdot 760$ & $20 \cdot 051$ \\
\hline Size liver, $\mathrm{cm}$. & $9 \cdot 5$ & 0 & 6 & 0 & $4 \cdot 7$ & $3 \cdot 8$ \\
\hline Size splecn, cm. . $\quad \ldots$ & 18 & $7 \cdot 5$ & 11 & $5 \cdot 4$ & $12 \cdot 3$ & $5 \cdot 4$ \\
\hline Hæmoglobin, per cent. & 50 & 27 & 72 & 5 & 38 & 63 \\
\hline Red blood cells & $4,592,000$ & $1,984,000$ & $4,752,000$ & $2,440,000$ & $2,915,000$ & $3,916,000$ \\
\hline White blood cells & 8,650 & 1,060 & $1 \mathrm{i}, 000$ & 5,000 & 3,832 & 6,973 \\
\hline
\end{tabular}

TABLE 6 .

Group D : Results of treatment by STIbosan 471.

\begin{tabular}{lr|c|c|c|c|c|c}
\hline & \multicolumn{2}{|c|}{ Before treatment. } & \multicolumn{2}{|c|}{ After treatiment. } & Before: & After : \\
\cline { 3 - 7 } & & Max. & Min. & Max. & Min. & Average. & A verage. \\
\hline Body wt., kgrm. & $\ldots$ & - & - & - & - & $19 \cdot 640$ & $21 \cdot 460$ \\
Size liver, cm. & $\ldots$ & 7 & 1 & 6 & 1 & $4 \cdot 1$ & $2 \cdot 4$ \\
Size spleen, cm. & $\ldots$ & 16.5 & - & 19 & 3 & - & $7 \cdot 3$ \\
Hæmogiobir, per & cent. & 75 & 18 & 80 & 32 & 48 & 62 \\
Red blood cells & $\ldots$ & $4,950,000$ & $2,448,000$ & $4,900,000$ & $2,500,000$ & $3,655,000$ & $4,130,000$ \\
White blood cells & $\ldots$ & 9,100 & 2,450 & 8,500 & 3,000 & 5,380 & 6,840 \\
\hline
\end{tabular}


Illustrative Gase (Group C).-Male, 8 years of age, had been ill with kala azar for 2 years. Spleen first enlarged 18 months before admission. Patient received stibamine glucoside, total gm. 1.92. The drug was given intravenously on alternate days, beginning with gm. 0.03 and gradually increasing to gm. $0 \cdot 1$ at the end of 12 days. This dose was continued until the total amount had been given.

TABLE 7.

Results in illustrative case in Group C.

\begin{tabular}{|c|c|c|c|c|c|}
\hline & & Admission. & $\begin{array}{l}\text { End of } \\
\text { treatment. }\end{array}$ & $\begin{array}{l}23 \text { months } \\
\text { after } \\
\text { discharge. }\end{array}$ & $\begin{array}{c}47 \text { months } \\
\text { after } \\
\text { dischargc. }\end{array}$ \\
\hline Spleen, enlarged & $\ldots$ & $18 \mathrm{~cm}$ & $11.5 \mathrm{~cm}$. & $6 \mathrm{~cm}$. & $0 \mathrm{~cm}$ \\
\hline Liver, enlarged... & $\ldots$ & $6 \mathrm{~cm}$. & $4.5 \mathrm{~cm}$ & $2 \cdot 5 \mathrm{~cm}$ & $0.5 \mathrm{~cm}$ \\
\hline Body wt. $\quad \ldots$ & $\cdots$ & $22 \cdot 5 \mathrm{ligrm}$ & $25 \mathrm{kgrm}$. & - & $33.03 \mathrm{kgrm}$. \\
\hline Serum globulin test & $\cdots$ & positive. & - & negative & - \\
\hline L. donovani $\quad$... & $\cdots$ & Liver positive & spleen neg. & spleen neg. & - \\
\hline Red blood cells ... & $\ldots$ & $2,272,000$ & 一 & $4,512,000$ & $4,900,000$ \\
\hline Hæmoglobin, per cent. & $\ldots$ & 27 & - & 68 & 82 \\
\hline White blood cells & $\ldots$ & 1,060 & - & 5,600 & 14,050 \\
\hline
\end{tabular}

Illustrative Case (Group D).-Male, about $\mathbf{5}$ years of age. Patient was brought to hospital by a friend of the family who said the patient had been suffering from afternoon fever for one month, and that the parents of the patient had noticed for one month a mass below the left costal margin. Patient remained in hospital 10 weeks receiving stibosan up to a total of $1.49 \mathrm{grm}$. The drug was given on alternate days intravenously in 2 per cent. solution. An initial dose of 0.03 grm. was gradually increased to $0.08 \mathrm{grm}$. near the end of the course. Ten weeks after this treatment was finished, the patient returned to hospital for re-examination. While at home,

TABLE 8.

Results in illustrative case in Group D.

\begin{tabular}{|c|c|c|c|c|c|}
\hline & $\begin{array}{c}\text { First } \\
\text { admission. }\end{array}$ & $\begin{array}{l}\text { End first } \\
\text { treatment. }\end{array}$ & $\begin{array}{l}\text { Second } \\
\text { admission. }\end{array}$ & $\begin{array}{l}\text { End second } \\
\text { treatment. }\end{array}$ & $\begin{array}{l}\text { Third } \\
\text { admission. }\end{array}$ \\
\hline Spleen, enlarged ... & $7 \cdot 5 \mathrm{~cm}$ & $6 \mathrm{~cm}$. & $5 \mathrm{~cm}$ & $4 \cdot 5 \mathrm{~cm}$ & $3 \mathrm{~cm}$. \\
\hline Liver, enlarged $\ldots$ & $4 \mathrm{~cm}$. & $3 \mathrm{~cm}$. & $4 \cdot 5 \mathrm{~cm}$ & $2.5 \mathrm{~cm}$ & $2.5 \mathrm{~cm}$ \\
\hline Body wt. $\quad \ldots$ & $18 \cdot 250 \mathrm{kgrm}$ & $22 \cdot 850 \mathrm{kgrm}$. & $20,580 \mathrm{kgrm}$. & $22 \cdot 300 \mathrm{kgrm}$. & $20 \cdot 300 \mathrm{kgrm}$. \\
\hline Serum globulin test & negative & - & negative & negative & negative \\
\hline L. donovani (spleen) & positive & positive & positive & - & negative \\
\hline Red blood cells & $3,032,000$ & $4,364,000$ & $4,950,000$ & $4,824,000$ & $5,100,01) 0$ \\
\hline Hæmoglobin, & 48 & 75 & 75 & 75 & 60 \\
\hline White blood cells... & 1,850 & 3,800 & 7,600 & 9,880 & 7,400 \\
\hline
\end{tabular}


patient had lost kilo $2 \cdot 270$. The spleen was $1 \mathrm{~cm}$. smaller than at time of discharge. L. donovani bodies were found in spleen puncture films. Stibosan was again given as in first course. Because of illness in family, patient was taken home when a total of $0.63 \mathrm{grm}$. had been given. One month after second discharge, patient returned for examination. Twenty-six months after last visit, a report indicated that patient was completely cured of kala azar.

Group E. There remain for consideration the group of cases treated by neostibosan by intravenous and intramuscular injections.

Number of cases treated, $\mathbf{3 4}$.

Average age, $7 \frac{1}{3}$ yr.

Average duration kala azar before treatment, 12 months.

Liver puncture positive for $\mathbf{L}$. donovani, 27.

Spleen ", , , , , 8.

Average days in hospital, 30.

Total average dose of drug, $1.6 \mathrm{grm}$.

Average number of injections, 11 .

$$
\text { , }, \quad \text { amount of drug to fall of temperature, } 1.47 \mathrm{grm} \text {. }
$$

TABLE 9.

\begin{tabular}{|c|c|c|c|c|c|c|c|}
\hline & & \multicolumn{2}{|c|}{ Before. } & \multicolumn{2}{|c|}{ After. } & \multirow{2}{*}{ Before. } & \multirow{2}{*}{ After. } \\
\hline & & Max. & Min. & Max. & Min. & & \\
\hline Body wt., kgrm. & $\ldots$ & - & - & - & - & $17 \cdot 717$ & $19 \cdot 160$ \\
\hline Size liver, $\mathbf{c m}$. & $\cdots$ & 8 & 0 & 10 & 0 & 4 & 4 \\
\hline , spleen, cm. & $\ldots$ & 17 & 5 & 17 & 0 & $11 \cdot 8$ & 8 \\
\hline Hæmoglobin, per & ant. & 78 & 17 & 80 & 40 & $43 \cdot 8$ & $59 \cdot 3$ \\
\hline Red blood cells & $\ldots$ & $4,448,000$ & $1,056,000$ & $5,728,000$ & $2,025,000$ & $3,014,521$ & $3,530,900$ \\
\hline White blood cells & $\ldots$ & 14,000 & 1,400 & 10,800 & 2,500 & 4.826 & 6,005 \\
\hline
\end{tabular}

Group E : Results of treatment by neostibosan.

Illustrative Gases (Group E).-(1) Female, 3 yr. 2 months of age. Ill with kala azar 7 months before admission; spleen enlarged 5 months. During first stay in hospital, patient received neostibosan intravenously, total dose of $1.6 \mathrm{grm}$. Doses of $0.1 \mathrm{grm}$. were given on successive days, except the third day when $0.2 \mathrm{grm}$. was given. There was no reaction following the injections. One month after treatment was finished, patient returned for observation and it was found that the spleen had enlarged during the interval. At this time a second course, total amount of neostibosan $0.5 \mathrm{grm}$. was given intravenously. A letter written 20 months after the last injection indicated that the patient was completely cured of kala azar.

(2). Male, 8 years of age, ill with kala azar for 12 months. Spleen had been enlarged for about one year. Patient received intramuscular injections of neostibosan, a total of $1.7 \mathrm{grm}$. The drug was administered in doses of $0.1 \mathrm{grm}$. first day in hospital and $\mathbf{0 . 2} \mathbf{g r m}$. on alternate days, until the full amount had been 
given. At the first return visit no treatment was given for kala azar. Patient was again brought back for second return visit because he was pale and did not gain strength. A written report 13 months after the second treatment was finished indicated that the kala azar had been cured.

(3). Male, 6 yrs. 11 months of age. Ill with kala azar 15 months. Spleen enlarged 12 months. Patient received intravenous injections of neostibosan gm. 0.05 for three successive days at beginning of treatment and then, gm. $0 \cdot 2$ daily until a total of gm. 1.75 was given. A letter received 13 months after treatment was finished indicated that the patient was cured of kala azar.

\section{Discussion.}

In discussing the efficacy of antimony preparations in treatment of kala azar and in estimating the proper total amount of the drug to be given, physicians agree that it is not possible to depend on any one laboratory or clinical finding as evidence that the patient is cured of kala azar. Films and cultures made from spleen and liver punctures may be negative while the patient still harbours Leishmania donovani in his body. While positive cultures indicate that the patient still harbours the infection, negative films and cultures have been found in cases which later showed that the patient was not cured of kala azar. It has been a constant finding in our cases that tests for serum globulin changes characteristic of kala azar are positive in cured cases for several months following completion of treatment with antimony. Taken in order of time, the clinical signs indicating improvement following treatment of kala azar with antimony are: (a) Cessation of fever; (b) increase in body weight; (c) reduction in size of spleen and liver; (d) increase in total leucocyte count; (e) increase in red cell count and hæmoglobin; (f) physical appearance of well being.

In cases which we have been able to follow we have found that, if the above clinical manifestations are maintained for two months after the course of antimony is finished, the patient is cured. The cases which have returned with recurrence report that, at the end of a month, there are recurrence of fever and renewed enlargement of the spleen. As our cases return to the endemic area where they contracted the disease, the possibility of re-infection has to be taken into account. This is an important question which, as far as we know, has not been investigated: does infection with $L$. donovani produce a lasting immunity after the kala azar has been cured?

In all cases, the parents are requested to bring the child back for re-examination one month after the antimony treatment is finished. A few return for this examination, but very few return for any later examination. It is the consensus of opinion of co-workers, who know the habits of these parents, that failure to return indicates that the patient is free from symptoms from which he originally sought relief. We of the West who do not appreciate fully the effort put forth in making a long country trip in China may be prone to doubt this statement. The unanswered requests for written reports on the condition of patients may be accounted for by the 
fact that the majority of the parents cannot read or write, and to secure the services of a writer often entails expenditure of time and money.

According to written reports and return visits for examination, we would tabulate known cured cases as in Table 10. All cases included in this report had finished their treatment at least six months before the report was written or the examination reported was done.

TABLE 10.

END RESUlts of treatment.

\begin{tabular}{c|c|c|c|c}
\hline \multirow{2}{*}{$\begin{array}{c}\text { Antimony } \\
\text { preparation. }\end{array}$} & $\begin{array}{c}\text { Number of } \\
\text { cases. }\end{array}$ & $\begin{array}{c}\text { Av. years after } \\
\text { last treatment. }\end{array}$ & \multicolumn{2}{|c}{ No evidence of kala azar. } \\
\cline { 2 - 4 } (a) & 15 & 7 & 0 & Letter. \\
(c) & 6 & 4 & 0 & 6 \\
(d) & 6 & $3 \frac{1}{2}$ & - & 6 \\
(e) & 23 & $1 \frac{1}{2}$ & 6 & 23 \\
(f) & 6 & $5 \frac{1}{2}$ & 0 & 6 \\
\hline
\end{tabular}

Cases known to be cured of kala azar, a total of 56 out of 134 who completed treatment.

\section{Conclusions.}

1. Antimony preparations in treatment of kala azar: Sodium antimony tartrate, antimosan, stibamine glucoside, stibosan and neostibosan will cure kala azar in children. It requires a long time for completion of a full course of tartar emetic. Reactions to the drug are frequent and there seems to be a direct relation between the use of this drug and the frequent occurrence of bronchopneumonia during a course of treatment with the drug. Of the other named antimony preparations, neostibosan requires the shortest period for administration of the full course. It can be administered intramuscularly without any untoward symptoms. The only reaction to this drug has been a very occasional nausea immediately following the injection.

2. Complete rest in bed, with proper diet, is necessary during treatment, if the optimum relief from clinical manifestations of kala azar is to be secured early.

3. The only criterion of cure in kala azar at present available is the gradual disappearance and continued freedom from symptoms and signs of the disease during and following the treatment.

We wish to express our thanks to Dr. E. B. Struthers for the privilege of allowing us to review the cases treated prior to 1924 and for his kindness in providing us with neostibosan before the drug was placed on the market. 
REFERENGES.

1. Scott, A. V., and Li, P. K., Arch. Dis. Child., London, 1932, VII, 59.

2. Adolph, W. H., J. Indust. \& Engineering Chem., 1921, XIII, 1099.

3. Napier, L. E., Indian Med. Gaz., Calcutta, 1928, LXIII, 445.

4. Struthers, E. B., China Med. J., Shanghai, 1927, XLI, 755. 